\title{
The significance of gypsum applied to mushroom compost, in particular in relation to the ammonia content
}

\author{
J. P. G. Gerrits \\ Mushroom Experimental Station, Horst (L), the Netherlands
}

Accepted: 15 September 1977

Key words: mushroom, gypsum, mushroom compost, ammonia

\section{Summary}

The way gypsum affects mushroom yield has been investigated. With gypsum the nitrogen loss in the compost is slightly reduced and the $\mathrm{pH}$ is decreased. Curvilinear relationships were established between the $\mathrm{NH}_{4}$ content of the compost at filling and the yield in the presence or absence of gypsum and with or without supplementation with soya bean meal. These curves (four parabolas) give a clear picture of the significance of gypsum under various circumstances. The optimum quantity of gypsum proved to be $25 \mathrm{~kg}$ per $1000 \mathrm{~kg}$ of horse manure. Its time of application is not very important, but an early application favours a uniform distribution and a longer action. The drop in $\mathrm{pH}$ caused by gypsum influences the dissociation of $\mathrm{NH}_{4}{ }^{+}$ions considerably, i.e. in the presence of gypsum less $\mathrm{NH}_{3}$ is present in the compost. A possible mechanism by which gypsum lowers the $\mathrm{pH}$ is discussed.

\section{Introduction}

During the preparation of compost for mushroom growing a specific microflora develops in the compost, and is responsible for the conversions taking place during composting. For the development of the right microflora two factors can be considered of primary ecological importance. The first one is the amount of water, which is directly responsible not only for the moisture content of the compost, but also for the amount of air present in the compost heap (Gerrits, 1972b). The second factor is the ammonia content. It has already been shown that for horse manure compost (Gerrits, 1977) as well as for synthetic compost (Gerrits, 1974) the optimum percentage of $\mathrm{NH}_{4}$ at filling amounts to $0.4 \%$ with a pH between 8.3 and 8.5. At the same time a relationship between this $\mathrm{NH}_{4}$ content and the length of the peak-heating process was established (Gerrits, 1976a).

Gypsum, normally added in a proportion of $25 \mathrm{~kg}$ but sometimes of $10-15 \mathrm{~kg}$ per $1000 \mathrm{~kg}$ of compost, also plays an important role. According to Pizer gypsum strongly affects the structure of the compost, whereas Treshow points out that $\mathrm{Ca}^{++}$ 
ions could prevent a harmful effect of an excess of $\mathrm{Na}^{+}, \mathrm{K}^{+}$and $\mathrm{Mg}^{++}$ions. $\mathrm{Ca}^{++}$ ions should also neutralize the oxalic acid produced by the mushroom mycelium. According to Kligman \& Pizer (1950) gypsum lowers the pH of the compost. Earlier investigations showed a highly variable influence of gypsum on yield, among others depending on the nature of the horse manure used and the amount of chicken manure added to it (Gerrits 1970, 1976a). Riber Rasmussen (1967) and Bech \& Riber Rasmussen (1968) could not demonstrate a positive effect of gypsum, but they added at the same time sulphate of ammonia and calcium carbonate to the compost.

In this paper a number of experiments, designed to obtain a better insight into the action of gypsum, will be discussed. The percentage of ammonia in the compost appears to play an important role. Also the influence of the quantity of gypsum and its time of application is studied.

In mushroom growing it is possible to supplement the compost immediately before casing with soya bean meal or similar materials. This method was developed by Sinden \& Schisler (1962) and Lemke (1963) and elaborated for practical Dutch circumstances by Gerrits (1972a, 1976b). In this paper attention will also be paid to the influence of gypsum and the percentage of $\mathrm{NH}_{4}$ in the compost on the supplementation of compost at casing time.

\section{Experimental}

The compost was prepared in heaps of either $600 \mathrm{~kg}$ or $750 \mathrm{~kg}$ of fresh horse manure. In most experiments 16 heaps were built into a continuous row without separation in order to function as one large pile. The turning schedule $-3,0,4$, 7,8 was used throughout unless otherwise indicated. On day -4 the fresh horse manure was weighed and on day -3 wetted with an amount of water dependent on the moisture content of the fresh manure. The quantity of water to be given was derived from previous work (Gerrits, 1972b). For every kg of chicken manure about 1.5 litre of water had to be added in order to achieve an equivalent moisture content of the compost at various levels of chicken manure (Gerrits, 1977). Normally chicken manure was applied on day 0 at the time of stacking and on day 4 the gypsum (standard $25 \mathrm{~kg} / 1000 \mathrm{~kg}$ of horse manure) was added just before turning. The gypsum used was plaster of Paris $\left(\mathrm{CaSO}_{4} \cdot 1 / 2 \mathrm{H}_{2} \mathrm{O}\right)$. In specially designed experiments the time of application of chicken manure and gypsum was varied. On day 7 there was another turning and on day 8 the trays or shelf units were filled with exactly $100 \mathrm{~kg}$ of compost per $\mathrm{m}^{2}$. Generally the peak-heating period lasted for 10 days and the mycelium growth 12 days. In some experiments $1 \mathrm{~kg}$ of soya bean meal per $\mathrm{m}^{2}$ was mixed into the compost just before casing. The compost was cased with $4 \mathrm{~cm}$ of a mixture of black peat, white peat and calcium carbonate. The $\mathrm{pH}$ of that mixture was 7.5. Cropping started usually three weeks after casing. The mushrooms were harvested for 5 weeks and all yields in this paper are expressed as $\mathrm{kg}$ cut mushrooms picked in 5 weeks per $\mathrm{m}^{2}$ and per $100 \mathrm{~kg}$ of compost at filling.

The average composition of the chicken manure was on a fresh weight basis: $37 \%$ moisture, $12 \%$ ash, $51 \%$ organic matter, $2.4 \% \mathrm{P}_{2} \mathrm{O}_{5}, 24.1 \% \mathrm{C}, 2.5 \% \mathrm{~N}$ 
and the $\mathrm{C}: \mathrm{N}$ ratio was 9.5 . The chicken manure comes from broilers held for 7 weeks in the pen on wood shavings. The fresh horse manure was supplied by the Compost Enterprise of the CNC (Cooperative Dutch Mushroom Growers' Association) at Ottersum. The average moisture content was $63 \%$ varying from 54$74 \%$ at the time of arrival.

All the supplements were given per ton of fresh horse manure independent of the variation in moisture content. The reason for this is discussed by Gerrits (1977).

The experiments were carried out either in experimental plots in shelves of $1.3 \mathrm{~m}^{2}$ in growing rooms of $120 \mathrm{~m}^{2}$ or in trays of $0.27 \mathrm{~m}^{2}$ in growing rooms of $25 \mathrm{~m}^{2}$. All the houses were treated according to the one-zone system. In the houses there are 5 layers with 16 plots or 18 trays in one layer. In most experiments factorial designs were used such as a $2^{4}$ or $4 \times 2 \times 2$ layout or as a randomized block design with 16 treatments in 4 or 5 replicates. The layers were considered as blocks and the treatments were randomized in the layers. The factor gypsum was studied in combination with other factors in 21 experiments. In fresh samples of compost ammonia was distilled off in the presence of magnesia $(\mathrm{MgO})$ to determine the ammonia content of the compost. This ammonia content in expressed as $\% \mathrm{NH}_{4}$ in the dry matter. In dried, finely ground samples $(0.5 \mathrm{~mm}$ mesh) ash was determined by burning at $600{ }^{\circ} \mathrm{C}$ carbon by burning the samples and weighing the $\mathrm{CO}_{2}$ and nitrogen according to the Kjeldahl method. The $\mathrm{pH}$ was measured immediately after the samples were taken and after one day just before the $\mathrm{NH}_{4}$ was determined.

\section{Results}

$\mathrm{N}, \mathrm{NH}_{4}, \mathrm{pH}$ and gypsum

In Fig. 1-4 the amount of chicken manure added per $1000 \mathrm{~kg}$ of horse manure is plotted against some parameters of the compost at filling and at spawning. The relevant relationships are all calculated with and without gypsum. Some data for

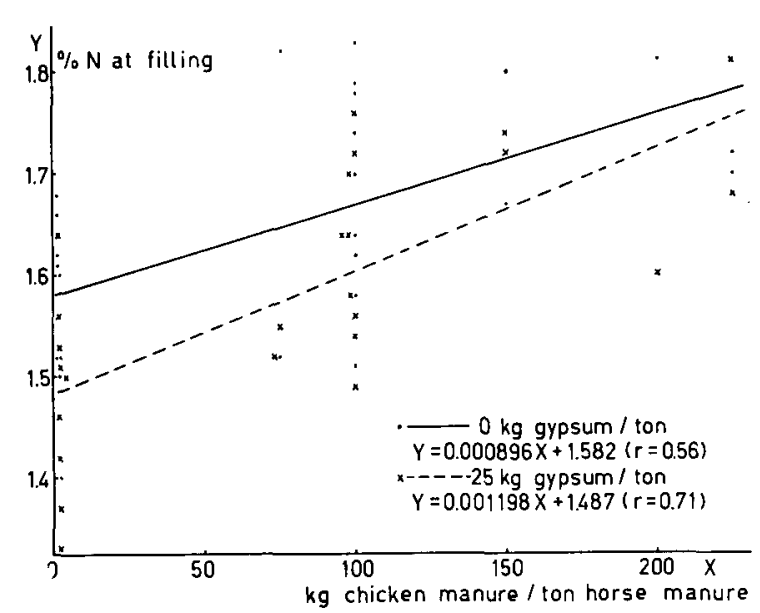

Fig. 1. Relationship between the amount of chicken manure added per $1000 \mathrm{~kg}$ of horse manure and the percentage $\mathrm{N}$ at filling with and without gypsum. 
Table 1. Some data derived from Fig. 1-4.

\begin{tabular}{|c|c|c|c|c|c|c|c|c|}
\hline \multirow{2}{*}{$\begin{array}{l}\text { Chicken } \\
\text { manure } \\
\text { (kg/1000 } \\
\mathrm{kg} \text { manure) }\end{array}$} & \multirow{2}{*}{$\begin{array}{l}\text { Gypsum } \\
\text { (kg/1000 } \\
\text { kg manure) }\end{array}$} & \multicolumn{4}{|c|}{ At filling } & \multicolumn{3}{|c|}{ At spawning } \\
\hline & & $\% \mathrm{~N}$ & $\% \mathrm{NH}_{4}$ & $\begin{array}{l}\mathrm{pH} \text { at } \\
\text { sampling }\end{array}$ & $\begin{array}{l}\mathrm{pH} \text { after } \\
\text { one day }\end{array}$ & $\% \mathrm{NH}_{4}$ & $\begin{array}{l}\mathrm{pH} \text { at } \\
\text { sampling }\end{array}$ & $\begin{array}{l}\text { pH after } \\
\text { one day }\end{array}$ \\
\hline 0 & 0 & 1.58 & 0.15 & 8.86 & 8.21 & 0.02 & 8.20 & 7.85 \\
\hline 100 & 0 & 1.67 & 0.36 & 9.02 & 8.44 & 0.06 & 8.49 & 8.07 \\
\hline 200 & 0 & 1.76 & 0.57 & 9.18 & 8.67 & 0.10 & 8.77 & 8.29 \\
\hline 0 & 25 & 1.49 & 0.19 & 8.41 & 7.83 & 0.01 & 7.55 & 7.28 \\
\hline 100 & 25 & 1.61 & 0.38 & 8.54 & 8.06 & 0.06 & 7.65 & 7.40 \\
\hline 200 & 25 & 1.73 & 0.56 & 8.67 & 8.28 & 0.12 & 7.75 & 7.51 \\
\hline
\end{tabular}

0,100 and $200 \mathrm{~kg}$ chicken manure derived from those figures are tabulated in Table 1. Fig. 1 shows that the $\mathrm{N}$ content of the compost increases slightly after the addition of chicken manure. With gypsum this $\mathrm{N}$ content is somewhat lower than without gypsum. This difference is a result of the influence of gypsum on the ash content of the compost.

Fig. 2 shows that the addition of chicken manure increases the $\mathrm{NH}_{4}$ content of the compost at filling more than the $\mathrm{N}$ content. There is no difference between the absence or presence of gypsum. A similar relationship between chicken manure and $\mathrm{N}$ and $\mathrm{NH}_{4}$ content of the compost at filling (only in the presence of gypsum) has already been shown (Gerrits, 1977). Fig. 3 shows a similar relationship between chicken manure and $\mathrm{NH}_{4}$ content at spawning time, i.e. after peak-heating. Also in this figure there is no difference between the lines with and without gypsum.

Fig. 4 shows the relationships between the amount of chicken manure and the $\mathrm{pH}$ at filling and at spawning time, with and without gypsum, determined directly after the samples were taken and after about one day. The following facts can be established.

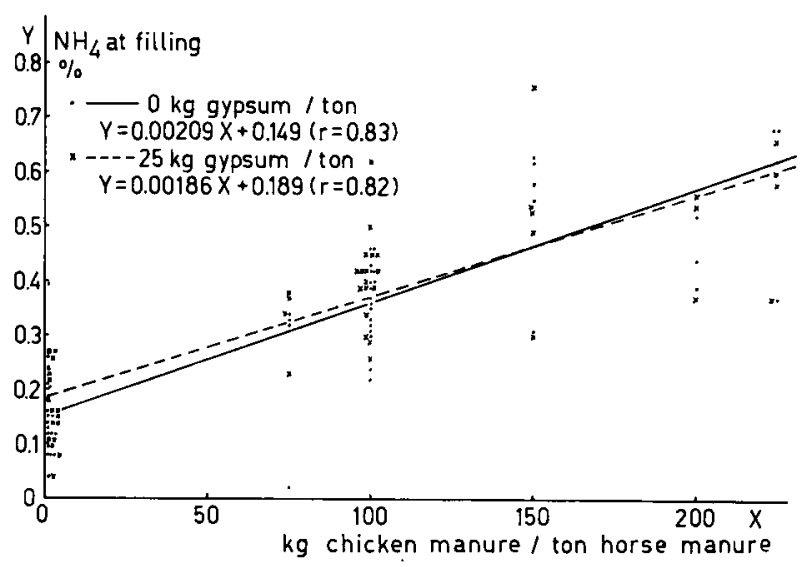

Neth. J. agric. Sci. 25 (1977)
Fig. 2. Relationship between the amount of chicken manure added per $1000 \mathrm{~kg}$ of horse manure and the percentage $\mathrm{NH}_{4}$ at filling with and without gypsum. 

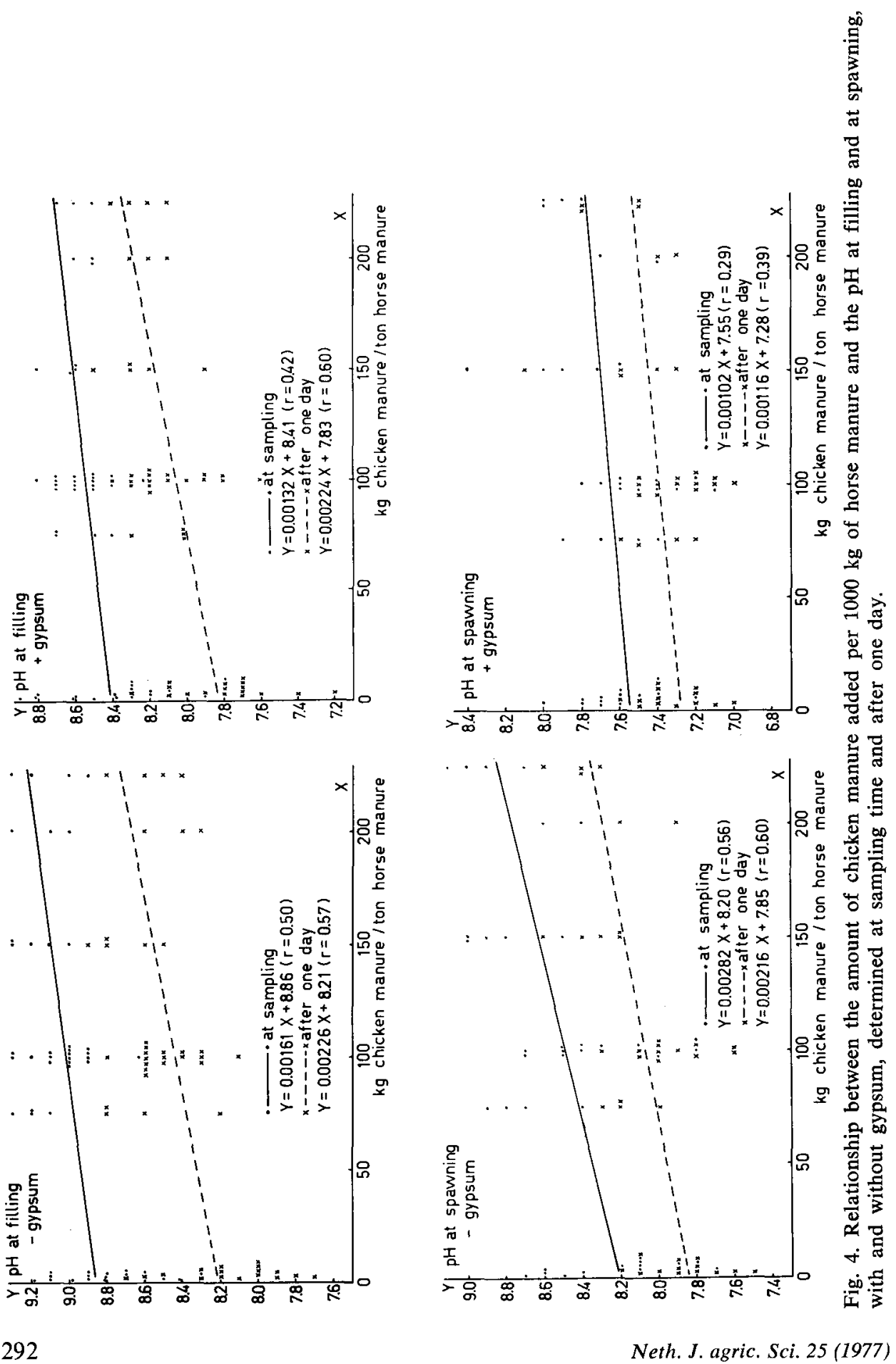


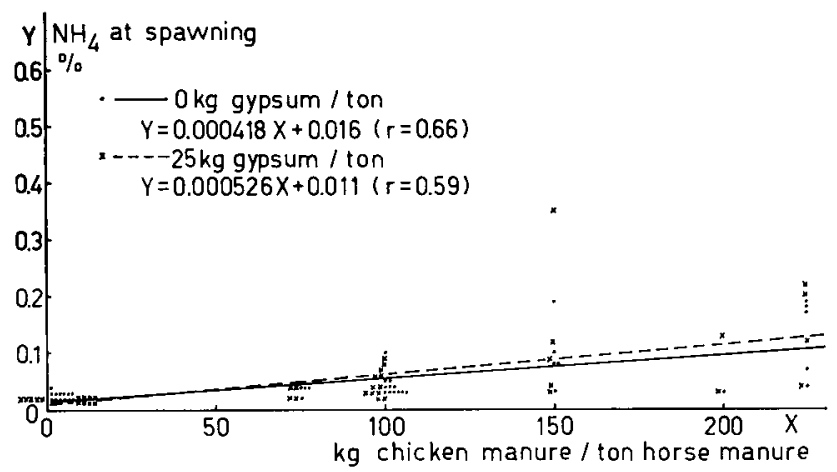

Fig. 3. Relationship between the amount of chicken manure added per $1000 \mathrm{~kg}$ of horse manure and the percentage $\mathrm{NH}_{4}$ at spawning with and without gypsum.

- The $\mathrm{pH}$ increases with increasing amounts of chicken manure, i.e. a higher $\mathrm{NH}_{4}$ content gives a higher $\mathrm{pH}$ (see also: Gerrits 1977).

- As a result of the addition of gypsum the $\mathrm{pH}$ decreases. The drop in $\mathrm{pH}$ at filling is smaller than at spawning.

- There is a considerable drop in $\mathrm{pH}$ during peak-heating, already a well-known fact.

- One day after sampling the $\mathrm{pH}$ is lower than immediately after sampling. This drop in $\mathrm{pH}$ depends on the initial $\mathrm{pH}$ value. Fig. 5 shows that the $\mathrm{pH}$ decreases more at high than at low initial $\mathrm{pH}$ values.

As has already been noticed the ash content of the compost increases with the addition of gypsum. Therefore the percentage organic matter as well as the percentage $\mathrm{N}$ and $\mathrm{NH}_{4}$ decreases.

Table 2 gives the $\mathrm{N}$ content at filling and the $\mathrm{NH}_{4}$ content, now converted as $\mathrm{NH}_{4}-\mathrm{N}$ at filling, as derived from Table 1. Besides, the data are expressed as percentages of the organic matter in order to eliminate the influence of gypsum on the ash content. For this purpose the ash content is used as calculated in Table 3 . Now

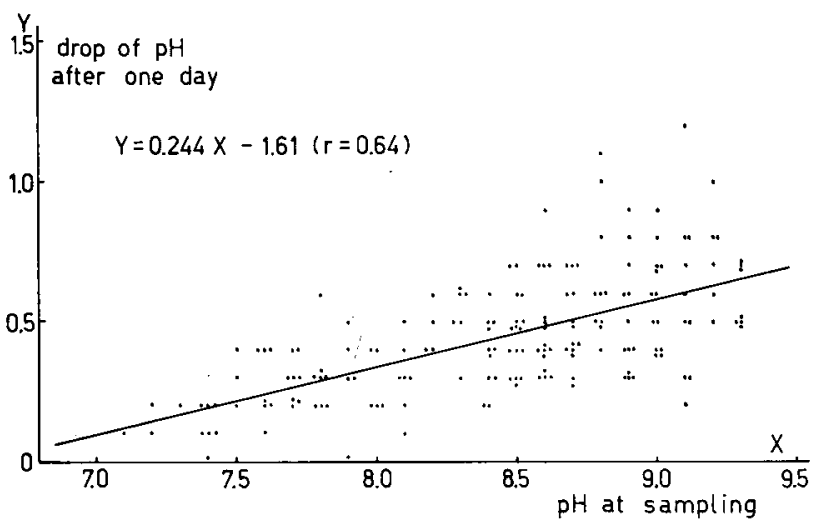

Neth. J. agric. Sci. 25 (1977)
Fig. 5. Relationship between the $\mathrm{pH}$ at sampling time and the drop of $\mathrm{pH}$ after one day. 
Table 2. Nitrogen balance at filling (calculated as percentages the organic matter).

\begin{tabular}{llllll}
\hline $\begin{array}{l}\text { Chicken } \\
\text { manure } \\
(\mathrm{kg} / 1000 \mathrm{~kg}\end{array}$ & $\begin{array}{l}\mathrm{Gypsum} \\
\mathrm{kg} / 1000 \mathrm{~kg} \\
\text { manure })\end{array}$ & $\% \mathrm{~N}$ & $\% \mathrm{NH}_{4}-\mathrm{N}$ & $\% \mathrm{~N}$-total & $\begin{array}{l}\mathrm{N} \text {-total } \\
\text { increase } \\
(\% \text { units })\end{array}$ \\
& & & & & \\
0 & 0 & 2.10 & 0.16 & 2.26 & \\
100 & 0 & 2.22 & 0.37 & 2.59 & \\
200 & 0 & 2.34 & 0.58 & 2.92 & \\
& & & & & \\
0 & 25 & 2.13 & 0.21 & 2.34 & +0.08 \\
100 & 25 & 2.30 & 0.42 & 2.72 & +0.13 \\
200 & 25 & 2.47 & 0.62 & 3.09 & +0.17 \\
\hline
\end{tabular}

it is clear that through the addition of gypsum the $\mathrm{N}$ content as well as the $\mathrm{NH}_{4}-\mathrm{N}$ content increases. Therefore the sum of both, i.e. N-total, is slightly higher with gypsum than without gypsum. In the presence of gypsum less $\mathrm{N}$ and $\mathrm{NH}_{4}$ disappears from the compost than in its absence.

\section{Gypsum, $\mathrm{NH}_{4}$ and yield}

The $\mathrm{NH}_{4}$ content of the compost at filling is a good measure of the quantity of nitrogen (e.g. chicken manure) added during the composting process. In Fig. 6 the yield of all experiments is plotted against the $\mathrm{NH}_{4}$ content of the compost at filling. The yields are expressed in $\mathrm{kg}$ per $\mathrm{m}^{2}$ and not converted as percentage yield as occurred in a previous series of trials (Gerrits, 1977). So the variation between the different experiments still exists. In spite of this a good parabolic relationship between the percentage $\mathrm{NH}_{4}$ and the yield was established. The parabola with gypsum closely resembles the one published before (Gerrits, 1977). In any experi-

Table 3. Some average data (determined or calculated) for compost with and without gypsum.

\section{Without gypsum With gypsum}

\section{Determined}

kg chicken manure/1000 kg horse manure $\quad 85$

$\begin{array}{lll}\mathrm{kg} \text { compost } / 1000 \mathrm{~kg} \text { horse manure } & 1070 & 1119\end{array}$

$\%$ moisture (at filling) $\quad 73.2$

71.4

$\%$ loss in dry matter during composting $\quad 29.4 \quad 26.4$

$\%$ ash (estimation) $\quad-\quad 30$

\section{Calculated}

kg dry matter (at filling) $\quad 287 \quad 320$

kg dry matter (start) $406 \quad 435$

kg loss in dry matter $\quad 119$

$\begin{array}{lrr}\mathrm{kg} \text { ash (at filling) } & 71 & 96\end{array}$

$\%$ ash (at filling) $\quad 24.7 \quad 30$

$\begin{array}{lll}\mathrm{kg} \text { dry matter per } \mathrm{m}^{2} & 26.8 & 28.6\end{array}$

$\begin{array}{lll}\mathrm{kg} \text { organic matter per } \mathrm{m}^{2} & 20.2 & 20.0\end{array}$ 


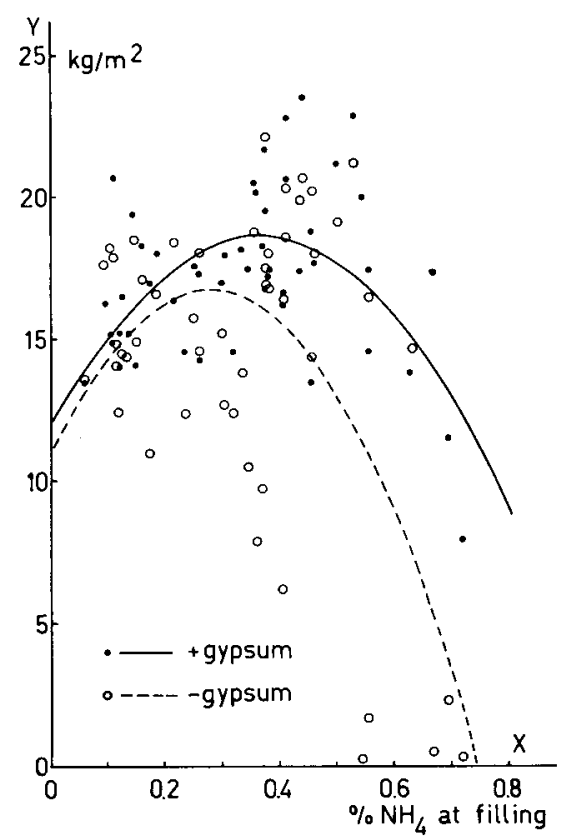

Fig. 6. Relationship between the $\% \mathrm{NH}_{4}$ at filling and the yield in $\mathrm{kg} / \mathrm{m}^{2}$ with and without gypsum. The regression equations are:

+ gypsum $Y=-50.92 X^{2}+37.19 X+11.91$

ment there was always a very significant interaction between the percentage $\mathrm{NH}_{4}$ and gypsum, i.e. in a poor compost with a low $\mathrm{NH}_{4}$ content gypsum does not effect yield whereas the effect of gypsum becomes more important as the $\mathrm{NH}_{4}$ content increases. The results of the individual trials are combined in the two curves in Fig. 6 and give a clear picture of the effect of gypsum. According to the graphs no mushrooms are produced at a $\mathrm{NH}_{4}$ content of $0.75 \%$ without gypsum, whereas the yield with gypsum still amounts to about $11 \mathrm{~kg}$ per $\mathrm{m}^{2}$ ! If chicken manure is used, extra water is added to the compost in most cases to achieve an equivalent moisture content in compost with and without chicken manure. The amount of water is not adjusted for gypsum. This resulted in an average moisture content of the compost at filling of $73.2 \%$ without gypsum and $71.4 \%$ with gypsum. The experimental plots were filled with $100 \mathrm{~kg}$ compost per $\mathrm{m}^{2}$ throughout. Therefore the plots without gypsum contain less dry matter per $\mathrm{m}^{2}$ than plots with gypsum. However, because the ash content increases with gypsum, the amount of organic matter per $\mathrm{m}^{2}$ is the same in both cases. Data used for this argument are shown in Table 3. For this reason no correction of the moisture content is applied in the calculation of the parabolas in Fig. 6.

\section{Yield per week}

Edwards (1949) established that the addition of gypsum influences the sequence of yield per week (flush). With gypsum his yields were better in the early weeks than in later ones. Table 4 shows the average weekly yield of all experiments with and without gypsum. These yields are also expressed as percentage of the total yield. 
Table 4. Yield per week with and without gypsum in $\mathrm{kg} / \mathrm{m}^{2}$ and in $\%$ (average yield from all experiments)

\begin{tabular}{llcccccc}
\hline & & W 1 & W 2 & W 3 & W 4 & W 5 & total \\
- gypsum & $\left(\mathrm{kg} / \mathrm{m}^{2}\right)$ & 3.3 & 5.3 & 3.0 & 1.6 & 1.1 & 14.3 \\
& $(\%)$ & 23 & 37 & 21 & 11 & 8 & 100 \\
+ gypsum & $\left(\mathrm{kg} / \mathrm{m}^{2}\right)$ & 3.9 & 6.7 & 3.9 & 2.2 & 1.4 & 18.1 \\
& $(\%)$ & 22 & 37 & 22 & 12 & 7 & 100 \\
\hline
\end{tabular}

The data show clearly that in those experiments the sequence of cropping is not affected by gypsum. The average increase in yield with gypsum is equally spread over all cropping weeks.

\section{Influence of supplementation with soya bean meal}

In six trials the compost was supplemented with $1 \mathrm{~kg}$ of soya bean meal per $\mathrm{m}^{2}$ just before casing (Sinden \& Schisler, 1962; Gerrits, 1972a, 1976b). It was already known that the increase in yield after supplementation is not always the same and that sometimes there is no effect at all. Fig. 7 shows that the percentage $\mathrm{NH}_{4}$ of the compost together with the use of gypsum can explain much of the variability in the results. In the individual experiments strong interactions could be demonstrated between $\mathrm{NH}_{4}$, gypsum and supplementation. In order to get a clear survey of the situation parabolas were calculated from the experimental data in the same way as indicated in Fig. 6. Corresponding curves agree well with each other.

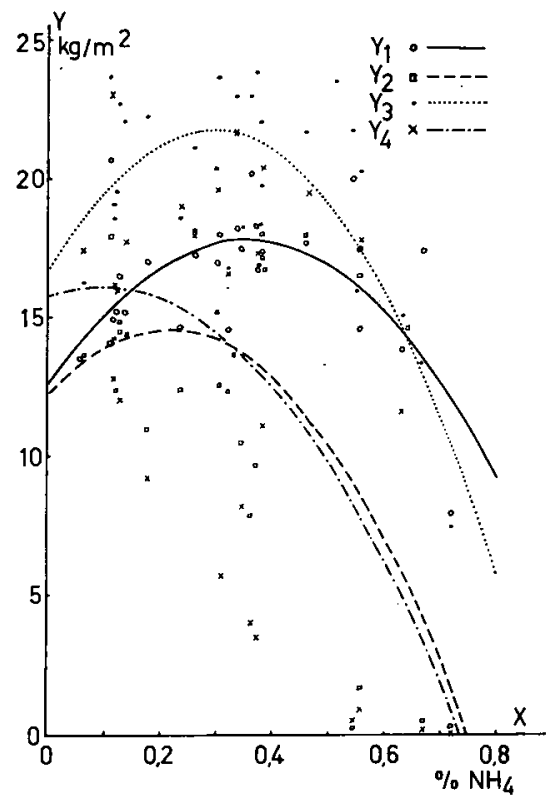

Fig. 7. Relationship between the $\% \mathrm{NH}_{4}$ at filling and the yield in $\mathrm{kg} / \mathrm{m} 2$ with and without gypsum and with and without supplementation with soya bean meal. The regression equations are

$\mathrm{Y}_{1}:+$ gypsum - soya : $\mathrm{Y}=-42.4 \mathrm{X}^{2}+29.62 \mathrm{X}$ $+12.63$

$\mathrm{Y}_{2}:$ - gypsum - soya : $\mathrm{Y}=-50.81 \mathrm{X}^{2}+21.81 \mathrm{X}$ $+12.29$

$\mathrm{Y}_{3}:+$ gypsum + soya $: \mathrm{Y}=-61.17 \mathrm{X}^{2}+35.53 \mathrm{X}$ $+16.63$

$\mathrm{Y}_{4}:-$ gypsum + soya $: \mathrm{Y}=-37.99 \mathrm{X}^{2}+7.05 \mathrm{X}$ 
Referring to Fig. 7 the following remarks can be made. If gypsum is present in the compost an increase in yield of $4 \mathrm{~kg}$ per $\mathrm{m}^{2}$ is obtained by supplementing $1 \mathrm{~kg}$ of soya bean meal per $\mathrm{m}^{2}$ in a compost with a low $\mathrm{NH}_{4}$ content. With an increasing $\mathrm{NH}_{4}$ content the effect of supplementation decreases. At an optimum $\mathrm{NH}_{4}$ content of $0.35 \%$ the effect is still over $3 \mathrm{~kg}$ per $\mathrm{m}^{2}$. Beyond this the effect decreases to turn at a $\mathrm{NH}_{4}$ content of $0.6-0.7 \%$ from positive to negative. The position of this turning-point has not to be considered as absolute, but this can vary from trial to trial according to the circumstances. On average, however, it gives a good indication. A combination of compost with $100 \mathrm{~kg}$ of chicken manure as used in practice and supplementation with soya bean meal gives the best results, whereas the risks remain limited. If compost without gypsum is supplemented, there is only some positive effect if the $\mathrm{NH}_{4}$ content is very low. Even from a $\mathrm{NH}_{4}$ content of $0.3 \%$ upwards (i.e. lower than the optimum with gypsum) the effect will be negative. Consequently gypsum has also a highly stabilizing influence on the result if supplementation with soya bean meal is practised.

\section{Quantity of gypsum}

In the experiments discussed so far $25 \mathrm{~kg}$ of gypsum per $1000 \mathrm{~kg}$ of horse manure was used throughout. In some experiments other quantities were used as well in order to check the optimum amount of gypsum. The result is shown in Table 5. These data show no influence of the amount of gypsum on the $\mathrm{NH}_{4}$ content at filling and at spawning. There is a definite influence on the $\mathrm{pH}$. With $25 \mathrm{~kg}$ the $\mathrm{pH}$ is lower than with $10 \mathrm{~kg}$. This difference is more explicit at spawning than at filling. With more than $25 \mathrm{~kg}$ gypsum there is no further decrease of the $\mathrm{pH}$. The difference between 10 and $25 \mathrm{~kg}$ is probably brought about by a greater difficulty in distributing small quantities in the compost. Theoretically as little as $10 \mathrm{~kg}$ should be an overdose (Edwards, 1974).

Table 5. Influence of the quantity of gypsum in $\mathrm{kg} / 1000 \mathrm{~kg}$ of fresh horse manure. The gypsum is applied on day 4 and $100 \mathrm{~kg}$ of chicken manure is used throughout.

\begin{tabular}{|c|c|c|c|c|c|c|c|c|}
\hline \multirow[t]{2}{*}{ Exp. No } & \multirow{2}{*}{$\begin{array}{l}\text { Gypsum } \\
\mathrm{kg} / 1000 \mathrm{~kg} \\
\text { manure }\end{array}$} & \multicolumn{3}{|l|}{ At filling } & \multirow{2}{*}{\multicolumn{2}{|c|}{$\frac{\text { At spawning }}{\mathrm{NH}_{4}(\%) \mathrm{pH}}$}} & \multicolumn{2}{|c|}{ Yield $\mathrm{kg} / \mathrm{m}^{2}$} \\
\hline & & $\%$ moisture & $\mathrm{NH}_{4}$ & $\mathrm{pH}$ & & & - soya & + soya \\
\hline \multirow[t]{4}{*}{325} & 0 & 72.9 & 0.43 & 8.8 & - & - & - & 20.7 \\
\hline & 25 & 73.5 & 0.45 & 8.3 & - & $\ldots$ & - & 23.6 \\
\hline & 50 & 69.9 & 0.44 & 8.4 & - & - & - & 22.5 \\
\hline & 75 & 69.0 & 0.40 & 8.4 & - & - & - & 23.3 \\
\hline \multirow[t]{3}{*}{433} & 0 & 72.2 & 0.22 & 8.8 & 0.03 & 8.2 & 18.1 & 18.0 \\
\hline & 10 & 73.0 & 0.25 & 8.4 & 0.04 & 7.8 & 17.3 & 19.7 \\
\hline & 25 & 70.3 & 0.30 & 8.3 & 0.02 & 7.2 & 17.3 & 21.2 \\
\hline \multirow[t]{3}{*}{443} & 0 & 74.4 & 0.31 & 8.7 & 0.03 & 8.0 & 15.2 & 19.6 \\
\hline & 10 & 71.9 & 0.26 & 8.3 & 0.03 & 7.5 & 16.0 & 19.3 \\
\hline & 25 & 70.4 & 0.29 & 8.2 & 0.03 & 7.2 & 17.0 & 20.4 \\
\hline
\end{tabular}


Table 6. Influence of the time of application of gypsum $(25 \mathrm{~kg}$ per $1000 \mathrm{~kg}$ or horse manure) on yield $\left(\mathrm{kg} / \mathrm{m}^{2}\right)$ and $\% \mathrm{NH}_{4}$ at filling ( $100 \mathrm{~kg}$ of chicken manure is added throughout on day 0$)$.

\begin{tabular}{|c|c|c|c|c|c|c|c|c|}
\hline \multirow[t]{2}{*}{ Exp. } & & \multirow{2}{*}{$\begin{array}{l}\text { Without } \\
\text { gypsum }\end{array}$} & \multicolumn{6}{|c|}{ With gypsum } \\
\hline & & & -4 & -2 & 0 & 2 & 4 & 7 \\
\hline $354 / 355$ & $\begin{array}{l}\mathrm{kg} / \mathrm{m}^{2} \\
\% \mathrm{NH}_{4}\end{array}$ & $\begin{array}{l}6.2 \\
0.42\end{array}$ & - & - & $\begin{array}{c}17.2 \\
0.38\end{array}$ & - & $\begin{array}{c}16.6 \\
0.39\end{array}$ & $\begin{array}{c}17.3 \\
0.37\end{array}$ \\
\hline 468 & $\begin{array}{l}\mathrm{kg} / \mathrm{m}^{2} \\
\% \mathrm{NH}_{4}\end{array}$ & $\begin{array}{c}19.9 \\
0.37\end{array}$ & - & - & $\begin{array}{c}21.0 \\
0.50\end{array}$ & - & $\begin{array}{c}17.4 \\
0.50\end{array}$ & - \\
\hline 495 & $\begin{array}{l}\mathrm{kg} / \mathrm{m}^{2} \\
\% \mathrm{NH}_{4}\end{array}$ & $\begin{array}{c}18.8 \\
0.32\end{array}$ & - & - & $\begin{array}{c}20.7 \\
0.40\end{array}$ & - & $\begin{array}{c}20.5 \\
0.39\end{array}$ & $\begin{array}{c}20.9 \\
0.35\end{array}$ \\
\hline 543 & $\begin{array}{l}\mathrm{kg} / \mathrm{m}^{2} \\
\% \mathrm{NH}_{4}\end{array}$ & $\begin{array}{c}20.1 \\
0.23\end{array}$ & $\begin{array}{c}21.8 \\
0.42\end{array}$ & - & $\begin{array}{c}21.8 \\
0.26\end{array}$ & - & $\begin{array}{c}21.8 \\
0.23\end{array}$ & - \\
\hline 551 & $\begin{array}{l}\mathrm{kg} / \mathrm{m}^{2} \\
\% \mathrm{NH}_{4}\end{array}$ & $\begin{array}{c}14.4 \\
0.53\end{array}$ & - & $\begin{array}{c}18.5 \\
0.60\end{array}$ & $\begin{array}{c}16.9 \\
0.59\end{array}$ & $\begin{array}{c}17.9 \\
0.49\end{array}$ & - & - \\
\hline
\end{tabular}

In the yield the difference between 10 and $25 \mathrm{~kg}$ of gypsum is only manifested if the compost is supplemented with soya bean meal. This indicates that under certain circumstances $25 \mathrm{~kg}$ is better than $10 \mathrm{~kg}$. Therefore $25 \mathrm{~kg}$ of gypsum is recommended as a standard. With more than $25 \mathrm{~kg}$ of gypsum the yield does not increase any more. (This last statement has to be considered in relation to the decreasing moisture content and increasing ash content, if the quantity of gypsum added increases.)

\section{Time of adding gypsum}

In five experiments the time the gypsum and chicken manure were added was varied. In these experiments there were also treatments without gypsum or chicken manure, whereas in other treatments $200 \mathrm{~kg}$ of chicken manure were used. On the whole the conclusions drawn from the experimental data agreed with those derived from Fig. 6. In Table 6 only variants with gypsum are shown, always with $100 \mathrm{~kg}$ of chicken manure added at day 0 .

The time gypsum was added showed no significant effect on yield in any of the experiments. Neither has the time any effect on the $\mathrm{NH}_{4}$ content and the $\mathrm{pH}$ at filling. Only the absence or presence of gypsum shows variable effects on yield depending on the type of manure used. As far as the quantity of chicken manure is concerned the following can be noted. Compost with chicken manure usually heats better than without chicken manure. It does not matter when chicken manure is added. The $\mathrm{NH}_{4}$ contents at filling increases slightly in proportion as the chicken manure is added later. Ammonia then has a shorter period of time in which to disappear. Only is the chicken manure is added the day before filling (day 7) does the uncontrolled variation between the replicates increase strongly, indicating less efficient distribution resulting in more variable yields. In this case the activity of the compost during peak heating is higher, and this is likely to be related to the higher $\mathrm{NH}_{4}$ content. 
To get a good crop the chicken manure and gypsum cannot be given too early, but for practical reasons it may be desirable to add chicken manure only after watering the fresh manure, and gypsum at the first or second turning. If chicken manure and gypsum are added rather late a less homogeneous compost will be the result.

\section{Discussion}

The $\mathrm{pH}$ of a compost is highly dependent on the time interval between sampling and determination. The $\mathrm{pH}$ of the samples decreases more at a high $\mathrm{pH}$ value than at a low one, suggesting a relationship with a loss of ammonia. However, no obvious drop of the ammonia content could be shown with decreasing $\mathrm{pH}$. Probably there are other possible explanations for this drop in $\mathrm{pH}$ such as the establishment of a new $\mathrm{NH}_{4}{ }^{+} \rightleftharpoons \mathrm{NH}_{3}+\mathrm{H}^{+}$equilibrium in the samples after cooling down.

The drop in $\mathrm{pH}$ during peak-heating probably is mainly caused by the disappearance of ammonia either by ventilating the mushroom houses or its incorporation by microorganisms. The first possibility seems to be the most important one.

The $\mathrm{pH}$ of the compost also decreases with the addition of gypsum. The quantity of ammonia under specific circumstances present as free $\mathrm{NH}_{3}$ depends on the $\mathrm{pH}$. This is accurately known for a solution of $\mathrm{NH}_{4}{ }^{+}$ions in water, e.g. at $25^{\circ} \mathrm{C}$ (Fig. 8). It is doubtful how far such a curve applies to a complex medium like compost. As a result of the high salt concentration in the compost the curve could move as a whole to the right or to the left or be less steep. Also the temperature has a strong influence on the dissociation of $\mathrm{NH}_{4}{ }^{+}$ions (Srinath \& Loehr 1974). However Fig. 8 gives a general picture of what happens to ammonia in the compost. The more chicken manure or other $\mathrm{N}$ source is added to the compost, the higher will be the $\mathrm{NH}_{4}$ content and the lower the 'available' $\mathrm{C}: \mathrm{N}$ ratio. At the same time the $\mathrm{pH}$ of the compost increases and in addition the $\mathrm{NH}_{4}{ }^{+} \rightleftharpoons \mathrm{NH}_{3}+\mathrm{H}^{+}$equilibrium moves to

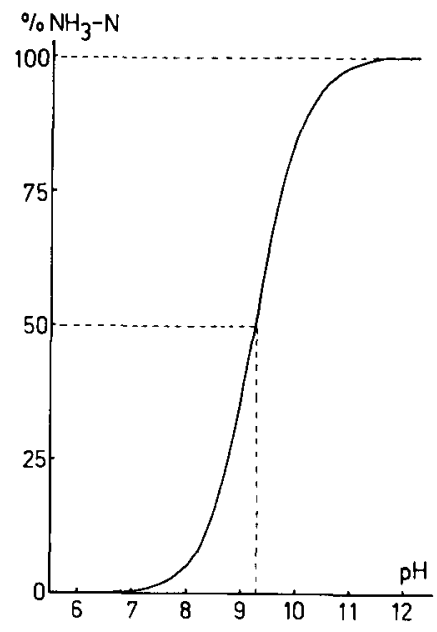

Fig. 8. Effect of $\mathrm{pH}$ on the fraction of undissociated ammonia in a solution of ammonia in water. 
the right. Therefore more $\mathrm{NH}_{3}$ disappears and the $\mathrm{pH}$ falls. Some sort of equilibrium arises at a certain $\mathrm{NH}_{4}$ content and a certain $\mathrm{pH}$. If the $\mathrm{pH}$ decreases further by adding gypsum the equilibrium just mentioned moves to the left. As a result less ammonia is present as free $\mathrm{NH}_{3}$. Fig. 8 shows that the dissociation of $\mathrm{NH}_{4}{ }^{+}$ions is considerably influenced by $\mathrm{pH}$ values between 8 and 9 . These values normally occur in compost. Building on thoughts developed by van Dijk (1971) a (hypothetical) explanation of the action of gypsum can be summarized schematically as follows:

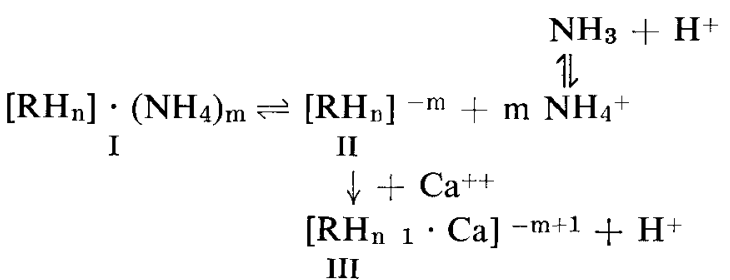

The organic matter-ammonium complex I can be considered as a salt of a weak acid (the anion II still carrying dissociable $\mathrm{H}^{+}$ions) and the weak base $\mathrm{NH}_{4} \mathrm{OH}$. The $\mathrm{NH}_{4}{ }^{+}$ion is in equilibrium with $\mathrm{NH}_{3}$ and $\mathrm{H}^{+} . \mathrm{NH}_{3}$ is volatile. The higher the concentration of $\mathrm{NH}_{4}+$ ions and the higher the $\mathrm{pH}$ is, the more $\mathrm{NH}_{3}$ volatilizes. $\mathrm{Ca}^{++}$ions of the well ionized $\mathrm{CaSO}_{4}$ (salt of a strong acid and a strong base) have a much greater affinity for II than $\mathrm{NH}_{4}$ ions and can even 'displace' (part of the) $\mathrm{H}^{+}$ions which are still bound. Moreover this gives rise to III and free $\mathrm{H}^{+}$ions (decrease of $\mathrm{pH}$ ), influencing the $\mathrm{NH}_{4}-\mathrm{NH}_{3}$ equilibrium, so that less $\mathrm{NH}_{3}$ volatilizes. Indeed Table 2 confirmed a smaller $\mathrm{N}$ loss after adding gypsum. $\mathrm{CaCO}_{3}$ has no effect on $\mathrm{pH}$. Some experiments in which various $\mathrm{N}$ levels were combined with various moisture contents indicated that less ammonia disappears from a wet compost than from a dry one. Probably more factors influence the ultimate $\mathrm{NH}_{4}$ content of the compost such as a high ambient temperature during composting resulting in reduced ventilation of the compost pile (chimney effect) and therefore leading to a high $\mathrm{NH}_{4}$ content. A possible effect of the quantity of chicken manure, with or without gypsum, on the microflora has not been checked.

Sometimes thermotolerant ink caps do occur. They are stimulated either by a combination of absence of gypsum and relatively low temperatures during conditioning, or by an overdose or late application of chicken manure.

At the time Pizer $(1937,1938)$ studied the function of gypsum, a much heavier type of manure was use with relatively more droppings but less additives. A long composting time in heaps of 5-6 m wide turned only once a week often resulted in greasy compost. In this situation the primary function of gypsum undoubtedly was improvement of the structure and aeration of the compost, because gypsum prevents greasiness.

Nowadays the heaps are narrower $(1.8-2.0 \mathrm{~m})$, and the manure contains more straw giving rise to a better structure and aeration. Therefore the influence of gypsum on $\mathrm{pH}$ and $\mathrm{NH}_{3}$ content is more pronounced than it was in the past. In a rich manure (poor in straw), that is relatively wet and with a high $\mathrm{NH}_{4}$ content, the 
beneficial effect of gypsum will be a combination of effects on $\mathrm{pH}$ and structure. A high $\mathrm{NH}_{4}$ content is associated with a high $\mathrm{N}$ content, and this latter with a low $\mathrm{C}: \mathrm{N}$ ratio. This can be achieved by adding a considerable quantity of $\mathrm{N}$ or by a prolonged composting time. The last procedure leads to damage of structure, that can partly be counteracted by gypsum. If the $\mathrm{C}: \mathrm{N}$ ratio is low and the structure right, then the effect of gypsum on $\mathrm{pH}$ is more important than the prevention of greasiness. The use of gypsum has been an enormous step forward in getting compost with a consistant yield.

Stoller (1962) described the influence of $\mathrm{NH}_{3}$ on the growth of mushroom mycelium. He noticed good growth at a $\mathrm{pH}$ of 7.3-7.6, at a lower $\mathrm{pH}$ the growth was even faster. The $\mathrm{NH}_{3}$ content at a $\mathrm{pH}$ of 7.3-7.6 was about $0.005 \%$. As early as 1945 Stoller showed that the $\mathrm{pH}$ is not a good measure for ammonia. If Fig. 8 can be assumed to be applicable to compost and if $0.005 \%(\mathrm{w} / \mathrm{w})$ is a safe level of $\mathrm{NH}_{3}$ in the compost, the following combinations of $\mathrm{pH}$ and $\mathrm{NH}_{4}+$ lead to favourable conditions for the mushroom mycelium.

$\begin{array}{lll}\mathrm{pH} & \mathrm{NH}_{4}+(\%) & \mathrm{NH}_{3}(\%) \\ 7.50 & 0.29 & 0.0051 \\ 7.75 & 0.16 & 0.0049 \\ 8.00 & 0.09 & 0.0048 \\ 8.25 & 0.06 & 0.0055 \\ 8.50 & 0.03 & 0.0045\end{array}$

The mushroom is sensitive to $\mathrm{NH}_{3}$, not to $\mathrm{NH}_{4}{ }^{+}$. The behaviour of fresh water fish in relation to ammonia is comparable with the mushroom (Anonymous, 1973). The mycelium grows well at pH values between 6.0 and 8.5 (Pizer, 1950; Treshow, 1944). This means that neither low levels of $\mathrm{NH}_{4}$ with a high $\mathrm{pH}$, nor a moderate amount of $\mathrm{NH}_{4}$ with a low $\mathrm{pH}$ is harmful. Only a combination of a high $\mathrm{pH}$ with high $\mathrm{NH}_{4}$ is harmful because this results in a high level of $\mathrm{NH}_{3}$ in the compost.

The best method to check if the compost is ready for spawning is not to determine the $\mathrm{pH}$ but to use a red litmus paper or a colorimetric absorption tube and a bellows pump as supplied by Dräger Limited, Lübeck, W. Germany (Kenny, 1975). A red litmus paper reacts on volatile bases such as $\mathrm{NH}_{3}$. For the measurement it is important to put the compost in a plastic bag to let the $\mathrm{NH}_{3}$ in the compost equilibrate with the air above. In further trials the effect of very low $\mathrm{pH}$ values in combination with high $\mathrm{NH}_{4}$ levels will be checked. For this purpose materials will be added to the compost that have a strong $\mathrm{pH}$ decreasing effect.

\section{Acknowledgments}

The author thanks R. C. Ross for correcting the English text and Dr H. van Dijk and Drs H. G. van Faassen from the Institute of Soil Fertility for their help in finding an explanation for the action of gypsum and for their critical comments on the manuscript. 


\section{References}

Anonymous, 1973. Water quality criteria for European fresh water fish. Report on ammonia and inland fisheries. Water Res. 7: 1011-1022. Pergamon Press.

Bech, K. \& C. Riber Rasmussen, 1968. Further investigations on organic and inorganic supplementation of mushroom compost. In: Mushroom science, Vol. 7: 329-342. Pudoc, Wageningen.

Dijk, H. van, 1971. Cation binding of humic acids. Geoderma 5: 53-67.

Edwards, R. L., 1949. Cropping experiments. A. Rep. Mushroom Res. Stn. (Yaxley, Peterborough) 1946-1948: 11-43.

Edwards, R. L., 1974. Why do we add gypsum to mushroom compost? Mushroom J. 16: 150-153.

Gerrits, J. P. G., 1970. Inorganic and organic supplementation of mushroom compost. Mushroom Grow. Ass. Bull. 251: 489-508.

Gerrits, J. P. G., 1972a. Praktische mogelijkheden van bijvoeden van champignoncompost. Champignoncultuur 16: 257-273.

Gerrits, J. P. G., 1972b. The influence of water in mushroom compost. In: Mushroom science, Vol. 8: 43-57.

Gerrits, J. P. G., 1974. Development of a synthetic compost for mushroom growing based on wheat straw and chicken manure. Neth. J. agric. Sci. 22: 175-194.

Gerrits, J. P. G., 1976a. Die Funktion organischer und anorganischer Zusätze im Champignonkompost, speziell hinsichtlich der Ammoniak-Konzentration. Champignon 175: 21-28; 176: 9-20.

Gerrits, J. P. G., 1976b. Welke resultaten zijn met bijvoeden te bereiken? Champignoncultuur 20: $279-295$.

Gerrits, J. P. G., 1977. The supplementation of horse manure compost and synthetic compost with chicken manure and other nitrogen sources. In: Mushroom science, Vol. 9 (Part 2) 77-98.

Kenny, A., 1975. Determination of ammonia in mushroom compost. Mushroom J. 30: 196-198.

Kligman, A. M., 1950. Handbook of mushroom culture. Business Press Inc., Lancaster, Pennsylvania.

Lemke, G., 1963. Champignonkultur auf nicht kompostiertem Strohsubstrat mit 'Startdüngung'. Dt. Gartenbauw. 11: 167-168.

Pizer, N. H., 1937. Investigations into the environment and nutrition of the cultivated mushroom, Psalliota campestris. I. J. agric. Sci. 27: 349-376.

Pizer, N. H. \& J. Thompson, 1938. Investigation into the environment and nutrition of the cultivated mushroom, Psalliota campestris. II. J. agric. Sci. 28: 604-617.

Pizer, N. H., 1950. Horse manure composts. In: Mushroom science, Vol. 1: 46-51.

Riber Rasmussen, C., 1967. Combination of sulphate of ammonia, calcium carbonate, superphosphate and gypsum and their influence on outside composting and cropping yield. In: Mushroom science, Vol. 6: 307-327. Pudoc, Wageningen.

Sinden, J. W. \& L. C. Schisler, 1962. Nutrient supplementation of mushroom compost at casing. In: Mushroom science, Vol. 5: 267-280.

Srinath, E. G. \& R. C. Loehr, 1974. Ammonia desorption by diffused aeration. J. Water Poll. Centr. Fed. 46: 1939-1957.

Stoller, B. B., 1945. Experiments in mushroom culture. Ph. D. Thesis. University of Wisconsin.

Stoller, B. B. (1962). Ammonia in compost, Part 2. Mushroom Digest 1962 (3): 49-53.

Treshow, C., 1944. The nutrition of the cultivated mushroom. Dansk bot. Ark. 11: 1-180. 